DOI: https://doi.org/10.24127/ajpm.v10i2.3490

\title{
E-LEARNING ARTIFICIAL INTELLIGENCE SEBAGAI SUPLEMEN DALAM PROSES METACOGNITIVE SCAFFOLDING PEMECAHAN MASALAH INTEGRAL
}

\author{
Cristina Resa Intan Permatasari ${ }^{1 *}$, Tri Nova Hasti Yunianta ${ }^{2}$ \\ ${ }^{1 *, 2}$ Pendidikan Matematika, Universitas Kristen Satya Wacana, Indonesia \\ Corresponding author. Jl. Diponegoro No.52-60 Sidorejo, Salatiga, Jawa Tengah, Indonesia \\ E-mail: $\quad \frac{\text { 202017007@student.uksw.edu }}{\text { trinova.yunianta@uksw.edu }}{ }^{2)}$
}

Received 19 January 2021; Received in revised form 18 June 2021; Accepted 29 June 2021

\begin{abstract}
Abstrak
E-learning artificial intelligence (AI) merupakan salah satu alat bantu dalam proses metacognitive scaffolding pemecahan masalah integral. Berkaitan dengan pernyataan tersebut, diperlukan penelitian untuk mengetahui bagaimana e-learning AI dapat membantu siswa dalam memecahkan masalah integral dan mengetahui bagaimana proses metacognitive scaffolding siswa SMA dengan adanya media tersebut. Penelitian kualitatif deskriptif ini dilaksanakan di SMA Negeri 3 Salatiga dengan 4 subjek yaitu siswa kelas 12, di mana keempat siswa sudah mempelajari materi dan mengetahui cara penyelesaian masalah mengenai integral. Teknik pengumpulan data yang digunakan untuk menyelesaikan masalah penelitian yaitu dengan menggunakan teknik tes, dokumentasi, wawancara hasil pemecahan masalah integral dimana diberikan 5 soal integral dalam bentuk cerita. Teknik analsis data dengan model analisis interaktif dari Miles dan Huberman. Berdasarkan hasil analisis data, menunjukkan bahwa dengan adanya bantuan $e$ learning AI yaitu dengan menggunakan aplikasi photomath siswa merasa terbantu dalam proses metacognitive scaffolding. Aplikasi tersebut dapat menjadi media tambahan dalam membantu siswa dengan hasil yang diberikan pada aplikasi tersebut didapat secara cepat dan terstruktur, sehingga siswa dapat memahami secara mudah setiap langkah yang disajikan.
\end{abstract}

Kata kunci: E-learning AI; metacognitif scaffolding; pemecahan masalah integral; suplemen.

\begin{abstract}
E-Learning of artificial intelligence $(A I)$ is one of the tools in the process of metacognitive scaffolding solving integral problems. As to that statement, it requires study to know how e-learning can help students solve integral problems and know how this process of metacognitive scaffolding students with the media. This descriptive qualitative study is carried out in the SMA Negeri 3 Salatiga with the 4 subjects of the 12th graders, where the four students have studied the material and learned how to solve the problem with the integral. Data collection techniques used to solve the research problem using tests, documentation, interviews with integrated problem solving, which were given five integral in story form. Interactive analysis model from Miles and Huberman is selected as the data analysis technique. Data analysis techniques Based on data analysis, it shows that with e's help using the photomath application, students find it helpful in the process of metacognitive scaffolding. The application can be a supplement to helping students with the results given on the application is obtained quickly and structured, so that students can easily understand each step presented.
\end{abstract}

Keywords: E-learning AI; Integral Problem Solving; metacognitif scaffolding, supplement.

This is an open access article under the Creative Commons Attribution 4.0 International License

\section{PENDAHULUAN}

Pada era globalisasi saat ini, teknologi berkembang sangat cepat dan semakin canggih. Efek perkembangan teknologi dan komunikasi yang semakin canggih telah memasuki sebuah era yang diberi nama yaitu era industri 4.0 (Rahman, 2019). Salah satu yang bisa 
menjadi tantangan pada era industri 4.0 yaitu dengan adanya pembelajaran secara online atau sering disebut $E$ Learning. Rahman (2019) mengatakan bahwa di era revolusi saat ini lebih menekankan kepada pola artifial intelligence, digital economy, robotic, dan lain sebagainya yang dikenal dengan distruptive innovation. Salah satu teknologi dalam Industri 4.0 yang dapat diterapkan pada dunia pendidikan adalah teknologi kecerdasan buatan (AI) (Mardhiyana \& Nasution, 2018: Pratikno, 2018). Aplikasi dari kecerdasan buatan yaitu dengan menggunakan robot untuk menggantikan tenaga manusia sehingga lebih murah, efektif, dan efisien (Ghufron, 2018). Salah satu robot sederhana bisa dibuat dalam bentuk perangkat lunak atau yang sering disebut dengan aplikasi yang saat ini sudah banyak terdapat pada smartphone. Smartphone dapat diisi aplikasi-aplikasi dengan konten untuk pendidikan dan ini dapat digunakan menjadi media belajar yang menarik dan menyenangkan bagi siswa (Abida \& Kusuma, 2019).

Hartanto (2016) mengatakan bahwa wujud berkembangnya teknologi yang bisa dimanfaatkan sebagai media pembelajaran yaitu menggunakan $e$ learning. Hakekat E-Learning yaitu bentuk pembelajaran konvensional yang berbentuk digital melalui teknologi internet (Hidayati, 2016). Media ini juga dapat menjadi media pembelajaran serta suplemen belajar dalam meningkatakan pemahaman siswa dalam belajar materi serta meningkatkan kualitas belajar dalam kelas (Hanum, 2013). Materi matematika SMA yang masih dirasa sulit oleh siswa adalah materi Integral dikarenakan materi integral merupakan materi yang kompleks (Yudianto,
2015). Dalam materi integral terdapat sub-sub materi yang harus dipelajari dan dipahami yang gunanya untuk melancarkan dalam materi yang akan dipelajarai selanjutnya. Belajar integral membutuhkan pemahaman konsep, latihan yang terus menerus dan menguasai materi prasarat dengan baik (Afandi, 2016). Dalam menyelesaikan masalah matematika siswa dituntut agar bisa mengontrol dan mengendalikan setiap proses berpikirnya. Kemampuan dalam mengontrol dan mengendalikan proses berpikir disebut dengan kemampuan metakognitif.

Terdapatnya kesulitan/kesalahan siswa dalam memecahkan masalah matematika, maka diperlukan Metacognitive Scaffolding. Murod (2015) mengatakan bahwa salah satu metode yang dapat digunakan saat siswa mengalami kesulitan dalam menyelesaikan masalah matematika yaitu Metacognitive Scaffolding. Metacognitive merupakan sebuah proses penggunaan ketepatan dari strategi dan esensi dalam berfikir seseorang.

\section{METODE PENELITIAN}

Metode penelitian yang digunakan adalah metode penelitian kualitatif. Alasan penggunaan metode kualitatif antara lain untuk mendeskripsikan dan menganalisis proses metacognitive scaffolding siswa SMA dalam memecahkan masalah integral dengan penggunaan E-Learning AI yaitu menggunakan aplikasi photomath. Subjek dalam penelitian ini yaitu 4 siswa kelas 12 dari SMA Negeri 3 Salatiga, dimana keempat siswa tersebut sudah mempelajari materi integral. Instrumen yang digunakan pada penelitian ini yaitu instrumen tes dengan materi integral, lembar 
DOI: https://doi.org/10.24127/ajpm.v10i2.3490

pedoman wawancara, dan dokumentasi.

Terdapat 3 tahap dalam menganalisis data. Adapun penjelasan dari ketiga tahap sebagai berikut.

\section{Tahap Persiapan}

Pada tahap persiapan ini menghubungi pihak sekolah untuk melakukan tes, dokumentasi dan wawancara pada siswa, yaitu di SMA Negeri 3 Salatiga. Adapun kesepakatakan dalam pemilihan siswa antara peneiliti dan pihak sekolah bahwa terdapat 4 siswa yang akan di teliti yaitu siswa kelas 12 MIPA 2 dimana keempat siswa tersebut sudah pernah mempelajari materi integral dan sesuai dengan kriteria dalam tahapan metacognitive scaffolding. Kemudian mempersiapkan soal yang akan dikerjakan oleh keempat siswa guna untuk mengetahui proses metacognitive scaffolding siswa dengan adanya $e$ learning $A I$ dalam menyelesaikan masalah integral.

\section{Tahap Pengumpulan Data}

Pada tahap ini diawali dengan mempersiapkan soal dan juga $e$ learning $A I$ yaitu menggunakan aplikasi. Setelah persiapan sudah selesai kemudian memberikan arahan dalam memecahkan masalah integral dalam bentuk soal cerita. Keempat siswa menyelesaikan soal cerita yang sudah dibagikan dengan menggunakan bantuan aplikasi yang dimiliki. Kemudian, setelah keempat siswa menyelesaikan soal cerita integral tersebut, secara bergantian guru melakukan wawancara kepada siswa. Wawancara ini dilakukan guna mengetahui bagaimana e-learning $A I$ bisa sebagai media tambahan dalam membantu siswa memecahkan masalah integral.

\section{Tahap Analisis Data}

Teknik analsis data yang digunakan adalah model analisis interaktif dari Miles dan Huberman (2007) dengan mengumpulkan data, mereduksi data, menyajikan data dan menarik kesimpulan. Pada tahap ini menganalisis dari hasil pengumpulan data dengan mengecek hasil jawaban siswa dalam mengerjakan masalah integral. Setelah data diolah maka terdapat proses siswa dalam mengerjakan masalah integral, maka dari situ terlihat proses metacognitive scaffolding pada setiap siswa dengan adanya aplikasi ini. Kemudian hasil dari wawancara akan dianalisis yaitu dengan menuliskan dalam bentuk naratif dan akan diambil kesimpulan dari data tersebut.

\section{HASIL DAN PEMBAHASAN}

Penelitian ini dilakukan dengan mengambil data di SMA Negeri 3 Salatiga tahun ajaran 2020/2021. Berdasarkan deskripsi hasil penelitian yang dilihat melalui hasil wawancara dan juga pengerjaan soal terhadap 4 siswa, penggunaan e-learning $A I$ dengan aplikasi photomath dapat menjadi media bantuan bagi siswa. Hal ini dapat dilihat dari jawaban yang dikerjakan bahwa semua siswa sudah dapat menyelesaikan masalah integral dari mengubah soal cerita dalam model matematika sampai ke solusi dari permasalahan tersebut. Melalui pengamatan jawaban dengan bantuan aplikasi photomath keempat subjek menghasilkan jawaban yang tepat sesuai dengan hasil yang ada di aplikasi.

E-Learning Artificial Intelligence dalam Pemecahan Masalah

E-learning AI merupakan salah satu bantuan dalam memecahkan masalah matematika. Model pembelajarn E-Learning merupakan 
salah satu sistem pembelajaran yang tepat bagi siswa karena e-learning membantu peserta didik untuk menambah informasi tentang konsep yang dipelajari melalui kegiatan belajar secara sistematis (Situmorang, 2016).

E-learning $A I$ yang digunakan dalam pemecahan masalah integral yaitu memakai aplikasi photomath. Franselaa \& Rangkuti (2019) mengatakan bahwa aplikasi yang dapat memecahkan permasalahan matematika dengan penjelasan langkah demi langkah dengan hanya menggunakan kamera belakang smartphone yaitu photomath.

E-Learning AI ini digunakan untuk membantu siswa dalam memecahkan suatu masalah matematika. Anwar \& Amin (2013) mengatakan bahwa untuk menyelesaikan suatu masalah diperlukan beberapa langkah yang sistematik. Dalam pemecahan masalah ini yang diperlukan yaitu adanya soal integral berbentuk cerita. Langkah awal dalam menyelesaikan soal cerita dengan menentukan terlebih dahulu model matematikanya. Setelah soal cerita dituliskan dalam model matematika, siswa dapat menyelesaikan dengan menggunakan aplikasi Photomath. Dapat dikatakan bahwa E-Learning AI dapat membantu dan mempermudah bagi siswa memecahkkan masalah integral. Bantuan yang diperoleh siswa melalui aplikasi yaitu dengan adanya jawaban yang didapat secara cepat dan juga terstruktur sehingga siswa dengan mudah memahami jawaban yang dihasilkan.

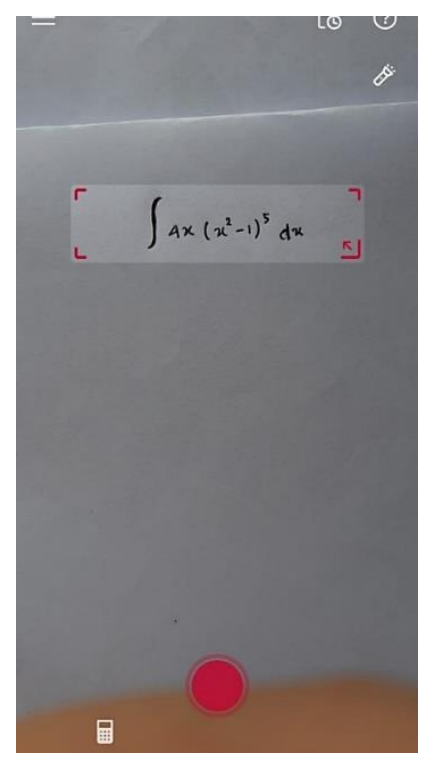

Gambar 1. Langkah awal mencari penyelesaian pada aplikasi

Berdasarkan Gambar 1 terdapat langkah selanjutnya yaitu menuliskan model matematika dalam aplikasi atau juga bisa melakukan foto penulisan model matematika yang sudah ditulis pada kertas. Setelah itu aplikasi photomath akan memproses soal tersebut sehingga mendapatkan hasilnya. Proses ini dapat dilihat pada Gambar 2. 
DOI: https://doi.org/10.24127/ajpm.v10i2.3490

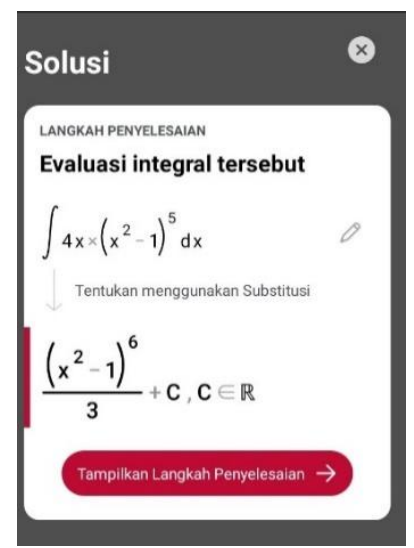

Gambar 2. Hasil setelah menuliskan model matematika pada aplikasi.

Pada Gambar 2. menunjukkan bahwa melalui aplikasi tersebut memberikan hasil dari model matematika yang dicari oleh siswa. Namun pada gambar tersebut belum ada penyelesaiannya. Siswa mendapatkan solusi dari hasil yang didapat tersebut dengan melanjutkan langkah selanjutnya yaitu dengan menampilkan langkah penyelesaian pada aplikasi.

$$
\begin{aligned}
& \int 4 x \times\left(x^{2}-1\right)^{5} d x \\
& 4 \times \int x \times\left(x^{2}-1\right)^{5} d x \\
& \begin{array}{l}
\text { Dengan menggunakan substitusi } t=x^{2}-1, \quad k^{\pi} \\
\text { ubahlah integralnya }
\end{array} \\
& 4 \times \int \frac{t^{5}}{2} d t \\
& 4 \times \int \frac{t^{5}}{2} d t
\end{aligned}
$$

Gambar 3. Petunjuk setiap penyelesaian pada jawaban aplikasi

Berdasarkan Gambar 3. Siswa diberikan petunjuk setiap penyelesaian yang dihasilkan oleh aplikasi. Pada tahap ini memiliki manfaat dimana siswa dapat terbantu saat memahami setiap langkah solusi yang diberikan karena setiap langkah solusi ditunjukkan bagaimana hasil tersebut didapatkan.
Setelah melakukan penyelesaian setiap jawaban dengan melihat langkah demi langkah yang diberikan oleh aplikasi, maka siswa dapat mamahami apa yang harus dituliskan pada lembar jawaban. Dapat dilihat bahwa hasil jawaban siswa ternyata sama dengan hasil aplikasi. Hal tersebut dapat dilihat pada Gambar 4 dan Gambar 5. 
DOI: https://doi.org/10.24127/ajpm.v10i2.3490

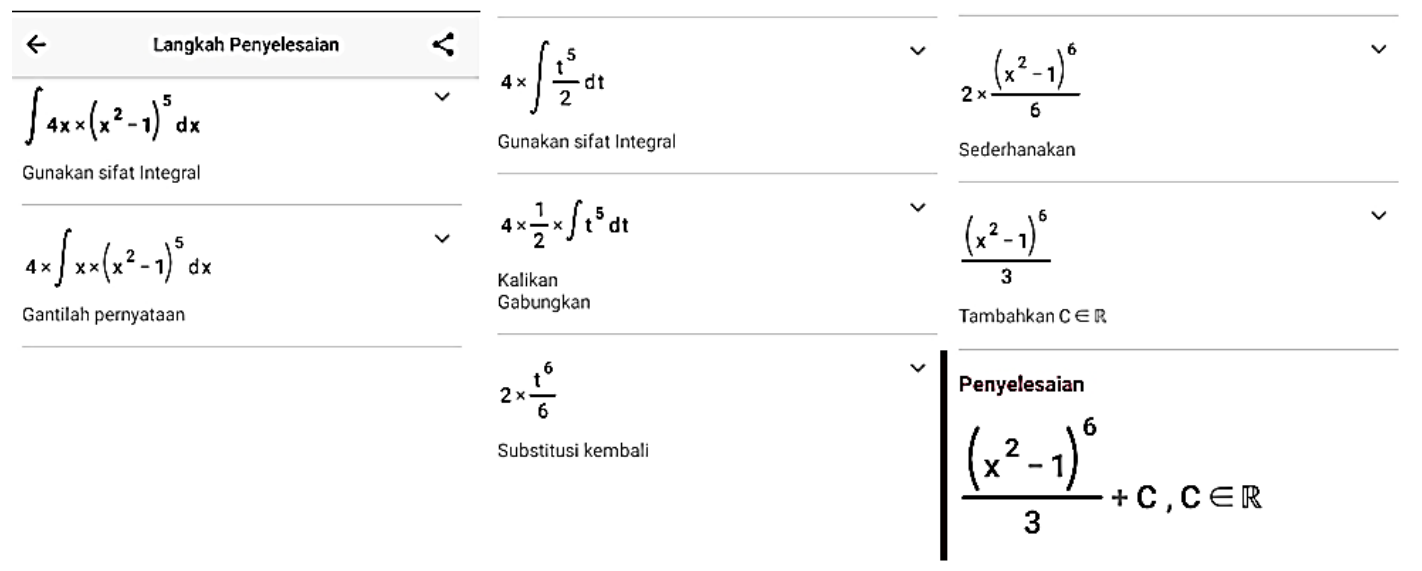

Gambar 4. Hasil penyelesaian soal nomer 4 dari photomath

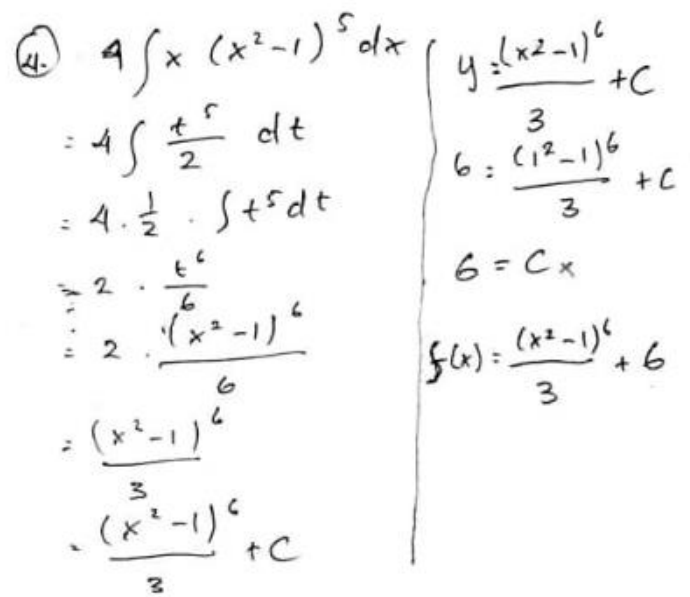

Gambar 5. Hasil penyelesaian soal yang dikerjakan siswa dengan bantuan aplikasi

Berdasarkan Gambar 4. dan Gambar 5. Terdapat hasil yang sama yang diperoleh melalui aplikasi dan hasil penyelesaian siswa. Hal tersebut terlihat bahwa siswa dapat terbantu dalam mengerjakan setiap soal yang diberikan dengan menggunakan aplikasi photomath.

E-Learning AI dengan penggunaan aplikasi photomath ini dapat menjadi salah satu alternatif media tambahan dalam memecahkan masalah integral. Dapat dilihat dari setiap proses yang dihasilkan oleh aplikasi sehingga siswa yang mencari dengan mudah mendapatkan solusi dari masalah tersebut. Hal ini sesuai dengan hasil penelitian (Franselaa \& Rangkuti, 2019) yang menyatakan bahwa penggunaan media pembelajaran android photomath dapat dijadikan sebagai alternatif untuk meningkatkan hasil belajar siswa, selain itu hal ini juga sesuai dengan penelitian (Kristiawati, 2020) yang menyebutkan bahwa adanya pengaruh terhadap kemampuan pemecahan masalah matematis setelah menerapkan model pembelajaran dengan E-Learning Artificial Intelligence.

Proses Metacognitive Scaffolding

Metacognitive Scaffolding merupakan salah satu komponen utama dalam pembelajaran, sebab guru dapat mengubah tugas yang rumit dan sulit menjadi tugas yang mudah untuk ditangani oleh siswa (Aminah et al., 
DOI: https://doi.org/10.24127/ajpm.v10i2.3490

2018). Dengan adanya Metacognitive Scaffolding diharapkan dapat mengatasi permasalahan yang dialami oleh siswa. Metacognitive Scaffolding yaitu suatu pendekatan yang dimulai dengan adanya arahan kepada siswa untuk memiliki kemampuan ketika mengatur suatu informasi yang telah didapat ke dalam penyelesaian masalah matematika (Ma'rufi et al., 2014).

Tabel 1. Tahapan metacognitive scaffolding

\begin{tabular}{lll}
\hline \multicolumn{2}{c}{ Tahapan } & \multicolumn{2}{c}{ Indikator } \\
\hline $\begin{array}{l}\text { Tahap Identifikasi Kemampuan } \\
\text { Siswa }\end{array}$ & Awal & $\begin{array}{l}\text { Memberikan rangsangan berupa beberapa } \\
\text { penyelesaian masalah materi integral }\end{array}$ \\
Tahap Analisis siswa menurut & $\begin{array}{l}\text { Mengelompokkan siswa berdasarkan } \\
\text { hasil skor yang didapat dari hasil ulangan } \\
\text { perkembangan kognitif }\end{array}$ \\
& harian \\
Tahap Pembelajaran & $\begin{array}{l}\text { Penjelaskan mengenai pokok bahasan } \\
\text { integral dan memberikan arahan kepada }\end{array}$ \\
& siswa yang kesulitan dalam \\
& menyelesaikan masalah integral \\
Tahap Permasalahan Integral & $\begin{array}{l}\text { Memberikan instruksi kepada siswa } \\
\text { dengan memanfaatkan } \\
\text { pembelajarann } \\
\text { Tahap Evaluasi }\end{array}$ & $\begin{array}{l}\text { Memberikan hasil siswa selama proses } \\
\text { pembelajaran }\end{array}$ \\
&
\end{tabular}

Tabel 1. Menunjukkan tahapan dan indicator menurut Murod (2015) yaitu tahapan pendekatan metacognitive scaffolding dengan aplikasi pemecahan masalah matematika. setiap tahap tersebut terdapat indicator yang dapat membantu dalam penelitian dengan pendekatan metacognitive scaffolding. Beberapa tahapan pada Tabel 1. Masih terbagi lagi yang terdiri dari input, proses, output, dan peranan aplikasi disajikan pada Tabel 2.

Sebelum melakukan tahap permasalahan, maka dilakukan tahap identifikasi kemampuan awal siswa, analisis menurut perkembangan kognitif dan tahap pembelajaran. Ketiga tahap ini sudah dilakukan saat siswa kelas 11 . Dengan bantuan guru di SMA Negeri 3 Salatiga dalam penelitian ini mendapat anjuran untuk melakukan penelitian kepada 4 siswa dari kelas 12 MIPA 2 yang dirasa sudah memenuhi dari ketiga tahapan tersebut.

Tabel 2. menjelaskan bahwa setelah keempat siswa sudah melakukan ketiga tahap, dapat dinyatakan bahwa keempat siswa tersebut sudah mempelajari materi integral, sehingga dapat melanjutkan pada tahap permasalahan integral. Pada tahap permasalahan ini terdapat 4 tahapan yang perlu dilakukan, yaitu, 1) tahap input; 2) tahap proses; 3) tahap output; dan 3) tahap peranan aplikasi. Sebelum melakukan tahap awal yaitu input, siswa mempersiapkan terlebih dahulu E-Learning AI yaitu aplikasi Photomath serta pemberian soal mengenai pemecahan masalah integral dalam bentuk cerita. 
DOI: https://doi.org/10.24127/ajpm.v10i2.3490

Tabel 2. Tahap Permasalahan dalam Metacognitive Scaffolding

\begin{tabular}{|c|c|c|}
\hline \multicolumn{2}{|c|}{ Tahapan } & Manfaat \\
\hline \multirow{4}{*}{$\begin{array}{c}\text { Tahap } \\
\text { Permasalahan } \\
\text { Integral }\end{array}$} & Input & $\begin{array}{l}\text { Peneliti menjadi fasilitator ataupun instruksi kepada } \\
\text { siswa, memberi motivasi dengan memanfaatkan media } \\
\text { pembelajaran }\end{array}$ \\
\hline & Proses & $\begin{array}{l}\text { Peneliti memberikan bantuan petunjuk atau arahan } \\
\text { mengenai permasalahan integral, sehingga siswa } \\
\text { merasa termotivasi atas dorongan dari guru. }\end{array}$ \\
\hline & Output & $\begin{array}{l}\text { Siswa dapat menyelesaikan permasalahan integral } \\
\text { dengan pemikiran yang telah diarahkan melalui bantuan } \\
\text { aplikasi, dapat membangun kognitifnya secara efisien, } \\
\text { dan mampu membuat suatu keputusan/solusi dari } \\
\text { permasalahan integral. }\end{array}$ \\
\hline & $\begin{array}{l}\text { Peranan } \\
\text { Aplikasi }\end{array}$ & $\begin{array}{l}\text { Membantu siswa dalam proses menyelesaikan } \\
\text { permasalahan integral, media aplikasi pemecahan } \\
\text { masalah matematika akan menjadi turor bagi siswa } \\
\text { dalam menyelesaikan permasalahan integral, dan dapat } \\
\text { memberikan lebih banyak penjelasan baru kepada } \\
\text { siswa. }\end{array}$ \\
\hline
\end{tabular}

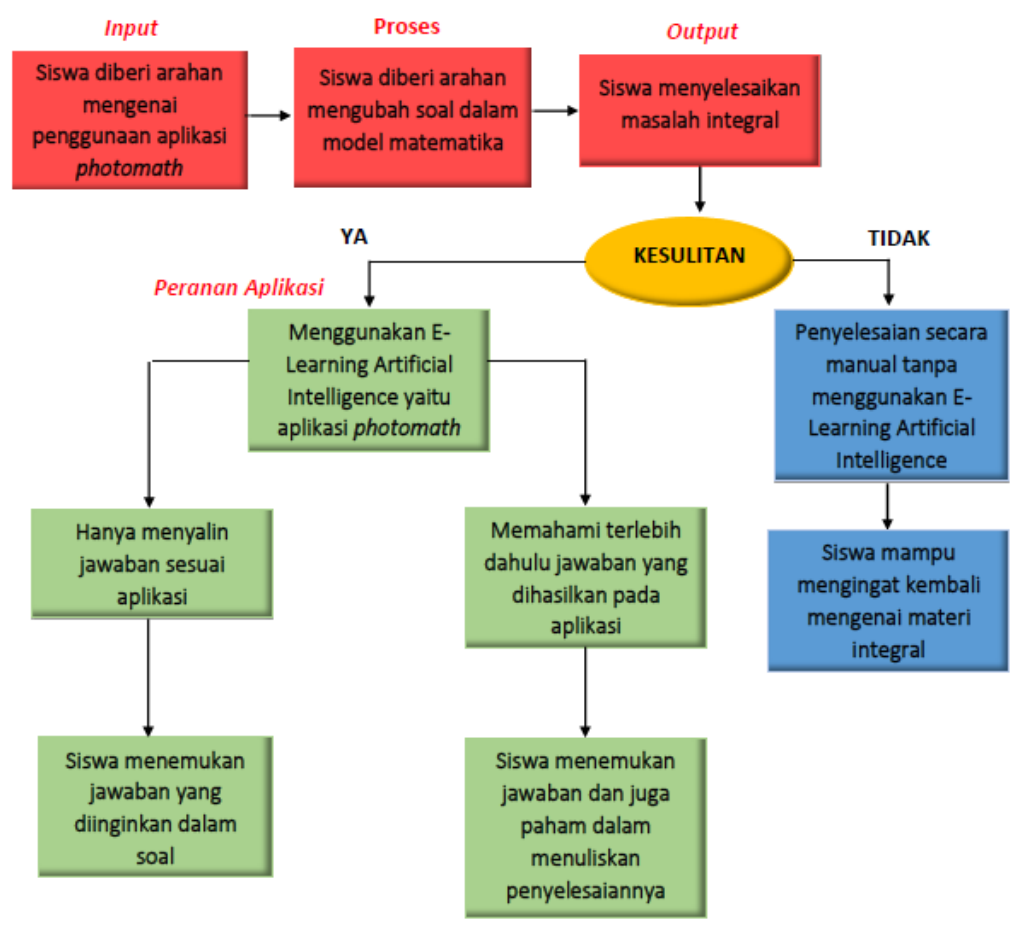

Gambar 6. Proses permasalahan integral dalam metacognitive scaffolding dengan penggunaan aplikasi photomath

Gambar 6 menjelaskan proses yang telah dilalui dalam penelitian ini. Pada tahap pertama yaitu input siswa diberikan arahan mengenai penggunaan aplikasi pemecahan masalah dalam menyelesaian masalah integral. Aplikasi yang digunakan oleh keempat siswa yaitu aplikasi photomath. Tahap proses 
memberikan petunjuk mengenai cara mengubah model matematika dari soal cerita yang telah diberikan dengan cara memberikan satu contoh soal cerita dan mengubahnya dalam model matematika. Tahap output siswa dapat menuliskan soal cerita dalam model matematika, lalu siswa dapat menyelesaikannya menggunakan bantuan aplikasi photomath. Terdapat dua tipe siswa saat menyelesaikan masalah integral dengan penggunaan aplikasi, yaitu; 1) terdapat siswa yang langsung menuliskan jawaban sesuai dengan penyelesaian yang ada pada aplikasi; 2) terdapat siswa yang memahami terlebih dahulu penyelesaian yang didapat melalui aplikasi. Tahap peranan aplikasi siswa dapat memproses informasi yang terdapat dalam aplikasi photomath sehingga siswa merasa terbantu dalam menyelesaikan masalah integral.

\section{KESIMPULAN DAN SARAN}

Berdasarkan hasil analisis, pengolahan data, pembahasan dan penelitisn mengenai E-Learning Artificial Intelligence sebagai suplemen dalam proses metacognitive scaffolding pemecahan masalah integral pada 4 siswa SMA Negeri 3 Salatiga, dapat disimpulkan bahwa dengan adanya $E$ Learning AI dapat menjadi suplemen dalam pemecahan masalah integral. Hal ini dapat dilihat dari hasil wawancara terhadap siswa dan keempat siswa mengatakan bahwa dengan adanya aplikasi photomath dapat menjadi salah satu media bantuan. Melalui proses yang telah dilakukan pada penelitian ini juga mendapatkan hasil proses metacognitive scaffolding siswa dengan bantuan E-Learning AI dalam menyelesaikan masalah integral, dimana dalam proses tersebut menunjukkan bahwa siswa dapat memahami setiap langkah yang diberikan oleh aplikasi photomath.

Beberapa saran yang dapat disampaikan berdasarkan penelitian yang sudah dilakukan adalah sebagai berikut: 1) guru matematika dapat mengaplikasikan adanya e-learning AI dalam pembelajaran, melihat perkembangan zaman yang semakin berkembang; 2) diharapkan siswa tetap dapat memahami setiap materi dalam pembelajaran dan dengan adanya $e$ learning $A I$ ini siswa dapat menggunakannya ketika merasa kesulitan dalam menyelesikan suatu masalah matematika namun harus dipahami terlebih dahulu hasil dari media ini; 3) untuk penelitian selanjutnya agar dapat melanjutkan penelitian mengenai E-Learning AI selain aplikasi photomath dalam membantu siswa memecahkan masalah matematika dan efektivitas adanya $E$ Learning AI dalam pemecahan masalah matematika.

\section{DAFTAR PUSTAKA}

Abida, R., \& Kusuma, A. B. (2019). Pemanfaatan mobile learning pada pembelajaran matematika di era revolusi industri 4.0. Prosiding Sendika, 5(1), 229-235. http://eproceedings.umpwr.ac.id/in dex.php/sendika/article/view/716/6 14

Afandi, A. (2016). Profil Penalaran Deduktif Siswa Smp Dalam Menyelesaikan Masalah Geometri Berdasarkan Perbedaan Gender. APOTEMA : Jurnal Program Studi Pendidikan Matematika, 2(1), 821.

https://doi.org/10.31597/ja.v2i1.12 3

Aminah, M., Kusumah, Y. S., Suryadi, D., \& Sumarmo, U. (2018). The effect of metacognitive teaching 
DOI: https://doi.org/10.24127/ajpm.v10i2.3490

and mathematical prior knowledge on mathematical logical thinking ability and self-regulated learning. International Journal of Instruction, 11(3), 45-62. https://doi.org/10.12973/iji.2018.1 $134 \mathrm{a}$

Anwar, S., \& Amin, S. M. (2013). Penggunaan Langkah Pemecahan Masalah Polya Dalam Menyelesaikan Soal Cerita Pada Materi Perbandingan Di Kelas Vi Mi Al-Ibrohimy Galis Bangkalan. Jurnal Pendidikan Matematika EPensa, 1(1), 1-6.

Franselaa, K., \& Rangkuti, E. F. (2019). Penerapan Pembelajaran Kooperatif The Learning Cell Berbantuan Aplikasi Android Photomath Pada Siswa SMP PAB 2 Helvetia Tahun Pelajaran 2017 / 2018. Prosiding SiManTap : Seminar Nasional Matematika dan Terapan I, Universitas Sumatera Utara, 521-525.

Ghufron, M. A. (2018). Revolusi industri 4.0: Tantangan, Peluang dan Solusi Bagi Dunia Pendidikan. Seminar Nasional dan Diskusi Panel Multidisiplin Hasil Penelitian Dan Pengabdian Kepada Masyarakat, 332-337.

Hanum, N. S. (2013). Keefetifan elearning sebagai media pembelajaran (studi evaluasi model pembelajaran e-learning SMK Telkom Sandhy Putra Purwokerto). Jurnal Pendidikan Vokasi, 3(1), 90-102. https://doi.org/10.21831/jpv.v3i1.1 584

Hartanto, W. (2016). Penggunaan ELearning sebagai Media Pembelajaran. Jurnal Pendidikan Ekonomi, 10(1), 1-18.

Hasanah, N., Suyanto, E., \& Suana, W. (2016). E-learning dengan
Schoology sebagai suplemen pembelajaran fisika materi elastisitas dan hukum Hooke. Jurnal Pembelajaran Fisika, 4(2).

Hidayati, N. (2016). Sistem E-Learning Untuk Meningkatkan Proses Belajar Mengajar: Studi Kasus Pada Sma Negeri 10 Bandar Lampung. Telematika MKOM, 2(2), 153-170. https://journal.budiluhur.ac.id/inde x.php/telematika/article/view/171

Kartika, H. (2014). Pembelajaran Matematika Berbantuan Software Matlab sebagai Upaya Meningkatkan Kemampuan Komunikasi Matematis dan Minat Belajar Siswa SMA. Jurnal Pendidikan Unsika, 2(1), 21-33. https://doi.org/10.22342/jpm.10.2. 3637.93-108

Kristiawati, I. (2020). Pengaruh Penerapan Model Pembelajaran Means Ends Analysis terhadap Kemampuan Pemecahan Masalah Matematika Siswa. Delta-Pi: Jurnal Matematika dan Pendidikan Matematika, 9(2), 48-67.

Ma'rufi, Ilyas, M., \& Fitriani, A. (2014). Pengembangan Bahan Ajar Matematika Berbasis Problem Posing Dengan Scaffolding Metakognitif Pada Smpn Kota Palopo. Seminar Nasional Pendidikan Karakter Di Gedung SCC Palopo, 01(1), 34-46.

Mardhiyana, D., \& Nasution, N. B. (2018). Kesiapan Mahasiswa Pendidikan Matematika Menggunakan E-Learning dalam Menghadapi Era Revolusi Industri 4 . 0. Seminar Nasional Pendidikan Matematika Ahmad Dahlan 2018, 2007, 31-35.

Murod, R. R. (2015). Pendekatan pembelajaran metacognitive scaffolding dengan memanfaatkan 
DOI: https://doi.org/10.24127/ajpm.v10i2.3490

multimedia interaktif untuk meningkatkan literasi matematis siswa SMA. Seminar Nasional Matematika dan Pendidikan Matematika UNY 2015, 705-712.

Pratikno, A. S. (2017). Implementasi Artificial Intelligence Dalam Memetakan Karakteristik, Kompetensi, dan Perkembangan Psikologi Siswa Sekolah Dasar Melalui Platform Offline. In Proceeding KMP Education Research Conference Keluarga Mahasiswa Pascasarjana (KMP) (pp. 18-27).

Rahman, M. H. (2019). Peranan Guru Dalam Mengembangkan Kreativitas Anak Usia Dini Melalui Metode Eksperimen Di Paud Asuhan Bunda Kabupaten Asahan. Jurnal Qurroti, 1(2), 3846.

Situmorang, A. S. (2016). Model Pembelajaran E-Learning Berbasis Web Terhadap Kemampuan Pemecahan Masalah Mahasiswa Prodi Pendidikan Matematika Fkip Universitas HKBP Nommensen T.A 2015/2016. JURNAL Suluh Pendidikan FKIP-UHN, 3(1), 15.

Yudianto, E. (2015). Profil Antisipasi Siswa SMA Dalam Memecahkan Masalah Integral. Kreano, Jurnal Matematika Kreatif-Inovatif, 6(1), 21.

https://doi.org/10.15294/kreano.v6i 1.4472 